\title{
Eating behaviors of high school baseball players in Japan
}

\author{
Tokie Izaki , Masahide Omori \\ From International Society of Sports Nutrition; 7th Annual ISSN Conference and Expo \\ Clearwater Beach, FL, USA. 24-26 June 2010
}

\section{Background}

Sport nutrition is important for preservation and promotion of health, the improvement of game ability and lifelong sports. Numerous research studies have been undertaken for various sports. In Japan, baseball is the most popular sport among high school students. Due to the number of the skills required for their period of growth, the time for their practice is generally long. In addition, the players and coach aim to increase their muscle mass power. Therefore, sport nutrition is expected to play an important role. The purpose of this study was to explore the actual condition of high school baseball players in relation to eating behavior.

\section{Methods}

The questionnaire survey was employed with high school baseball players (172 boys, 15-18 year olds) to investigate their perceived physical conditions, issues related to eating behavior, water intake, supplement intake and the time spent for sleeping per day. Similarly, the characteristics of each baseball club, were explored through the interviews of head coach.

\section{Results}

Almost $80 \%$ of students perceived their health as good. Stomach pain (16.67\%) and prolonged recovery from tiredness (14.29\%) were reported. Lack of dinner and breakfast, small amounts of vegetable intake, and limited knowledge of well-balanced meal were prevalent. Almost all the students $(n=171)$ reported that they drank water during exercise. However, it was noted that almost half of students $(48.3 \%)$ only consume water when they feel thirsty. Tea (48.3\%) and sport drink (38.4\%) were frequent. Regarding the supplement intake, $44.8 \%$ of

Tokai Gakuin University, 5-68 Nakakirinocho Kakamigaharashi Gifuken 504-8511, Japan students reported they were currently taking supplements either every day (45.5\%) or just three or four times per week (28.6\%). More than half of students (59.3\%) reported about sleeping about 6 hours per day.

\section{Conclusion}

Most of students reported that they were healthy, keeping regular hours and having well-balanced meals. It was of some concern that they might have limited knowledge of sport nutrition. Further research is required to explore differences between the regular players and the irregular players.

\section{Acknowledgement}

The authors appreciate for all students and coach those who helped with this study.

Published: 15 September 2010

doi:10.1186/1550-2783-7-S1-P18

Cite this article as: Izaki and Omori: Eating behaviors of high school baseball players in Japan. Journal of the International Society of Sports Nutrition 2010 7(Suppl 1):P18.

Submit your next manuscript to BioMed Central and take full advantage of:

- Convenient online submission

- Thorough peer review

- No space constraints or color figure charges

- Immediate publication on acceptance

- Inclusion in PubMed, CAS, Scopus and Google Scholar

- Research which is freely available for redistribution

Submit your manuscript at www.biomedcentral.com/submit
Biomed Central 